\title{
PEMANTAUAN 1000 HARI PERTAMA KEHIDUPAN DALAM RANGKA PENCEGAHAN STUNTING MELALUI PELATIHAN KADER KESEHATAN DI DESA MENEMENG WILAYAH KERJA PUSKESMAS BAGU KECAMATAN PRINGGARATA KABUPATEN LOMBOK TENGAH TAHUN 2018
}

\author{
Baiq Eka Putri Saudia ${ }^{1}$ dan Ni Putu Dian Ayu Anggraini ${ }^{2}$ \\ 'Program Diploma (DIV) Jurusan Kebidanan Politeknik Kesehatan Kemenkes Mataram \\ ${ }^{2}$ Program Diploma (D III) Jurusan Kebidanan Politeknik Kesehatan Kemenkes Mataram
}

\begin{abstract}
Abstrak
Seribu hari pertama kehidupan (1000 HPK) merupakan periode emas seorang anak untuk tumbuh dan berkembang secara optimal. Gangguan yang terjadi pada periode ini, akan berdampak pada kelangsungan hidup dan tumbuh kembang anak yang bersifat permanen dan berjangka panjang serta lebih sulit untuk diperbaiki setelah anak berusia 2 tahun sehingga akan menyebabkan salah terjadinya stunting. Penelitian ini bertujuan untuk pemberian pelatihan terkait 1000 HPK terhadap pengetahuan dan sikap kader kesehatan. Desain penelitian ini adalah pra-experimental one-group pretest-posttest design dengan responden kader kesehatan sebanyak 30 orang. Penelitian dilakukan bulan Maret sampai dengan Mei 2017. Hasil penelitian menunjukkan terdapat hubungan signifikan $(p<0.05)$ antara umur, pendidikan, pendapatan, dan pendidikan ayah terhadap pengetahuan dan sikap terkait 1000 HPK. Terdapat pula hubungan signifikan antara pendidikan ibu dengan pengetahuan terkait 1000 HPK. Namun tidak terdapat hubungan signifikan antara pendidikan ibu dengan sikap terkait 1000 HPK. Sedangkan besar keluarga dan jumlah sumber informasi tidak memiliki hubungan signifikan $(\mathrm{P}>0.05)$ dengan pengetahuan dan sikap terkait 1000 HPK. Pemberian edukasi memberikan efek positif terhadap pengetahuan dan sikap calon pengantin wanita. Terdapat peningkatan yang signifikan pada pengetahuan dan sikap setelah diberi edukasi.
\end{abstract}

Kata Kunci: 1000 HPK; Kader Kesehatan; Pelatihan

\begin{abstract}
The first thousand days of life (1000 HPK) is a golden period for a child to grow and develop optimally. Disorders that occur in this period, will have an impact on the survival and development of children who are permanent and longterm and are more difficult to be repaired after children aged 2 years so that it will cause stunting. This study aims to provide training related to 1000 HPK on the knowledge and attitudes of health cadres. The research design was a preexperimental one-group pretest-posttest design with 30 health cadre respondents. The study was conducted from March to May 2017. The results showed there was a significant relationship $(p<0.05)$ between age, education, income, and father's
\end{abstract}


education to knowledge and attitudes related to $1000 \mathrm{HPK}$. There is also a significant relationship between mother's education and knowledge related to 1000 HPK. But there is no significant relationship between maternal education with attitudes related to 1000 HPK. While family size and the number of sources of information have no significant relationship $(\mathrm{P}>0.05)$ with knowledge and attitudes related to $1000 \mathrm{HPK}$. Providing education has a positive effect on the knowledge and attitudes of brides-to-be. There was a significant increase in knowledge and attitudes after being educated.

Keywords: 1000 HPK; Health Cadres; Training

\section{Pendahuluan}

Meningkatnya sumber daya manusia yang sehat, cerdas dan produktif merupakan komitmen global dan merupakan aset yang sangat berharga bagi bangsa dan negara maka untuk mewujudkannya dapat dilakukan dengan cara perbaikan gizi secara terus menerus yang didukung dengan gerakan nasional 1000 hari pertama kehidupan ${ }^{6}$.

Peraturan Presiden nomor 42/2013 tentang Gerakan Nasional Perbaikan Gizi diterbitkan untuk mendukung upaya penggalangan partisipasi dan kepedulian pemangku kepentingan secara terencana dan terkoordinir untuk percepatan perbaikan gizi dalam 1000 hari pertama kehidupan (1000 HPK). Dengan demikian, instrumen pendukung kebijakan dalam percepatan perbaikan gizi sudah cukup lengkap, dan membutuhkan upaya implementasi yang terorganisir dan dapat diterapkan disetiap tingkatan oleh setiap elemen yang terlibat. Dengan terbitnya Perpres ini, dibutuhkan upaya yang lebih konkrit, fokus pada 1000 HPK dan integrasi kegiatan secara lintas program (upaya spesifik) maupun lintas sektoral (upaya sensitif) oleh semua stakes holders ${ }^{6}$.

Periode 1000 hari pertama kehidupan (1000 HPK) merupakan simpul kritis sebagai awal terjadinya pertumbuhan Stunting, yang sebaliknya berdampak jangka panjang hingga berulang dalam siklus kehidupan. Kurang gizi sebagai penyebab langsung, khususnya pada balita berdampak jangka pendek meningkatnya morbiditas. Bila masalah ini bersifat kronis, maka akan mempengaruhi fungsi kognitif yakni tingkat kecerdasan yang rendah dan berdampak pada kualitas sumberdaya manusia. Pada kondisi berulang (dalam siklus kehidupan) maka anak yang mengalami kurang gizi diawal kehidupan (periode $1000 \mathrm{HPK}$ ) memiliki risiko penyakit tidak menular pada usia dewasa ${ }^{9}$.

Data dari Dinas Kesehatan Provinsi Nusa Tenggara Barat Tahun 2018 menyebutkan bahwa Kabupaten Lombok Tengah merupakan salah satu kabupaten di NTB yang menyumbang prevalensi stunting kedua yaitu mencapai 39,9\% dimana angka ini turun bila dibandingkan dengan tahun 2013 yang menduduki peringkat pertama yaitu 47,79 \%. Sedangkan dari Data Dinas Kesehatan Lombok Tengah Tahun 2018, salah satu Desa di Kabupaten Lombok Tengah yang menyumbang stunting tertinggi yaitu di Desa Menemeng dengan jumlah balita stunting 114 balita yang terdiri dari katagori sangat pendek berjumlah 32 balita dan katagori pendek 82 balita $^{2}$. Oleh sebab itu penanggulangan stunting dapat 
dicegah dari awal melalui pemantauan 1000 HPK yang menjadi tanggung jawab semua pihak baik pembuat kebijakan maupun petugas kesehatan dan masyarakat sekitar.

Kader Kesehatan sebagai salah satu sumber informasi bagi masyarakat memegang peranan penting dalam kebenaran informasi yang diterima oleh masyarakat sebagai modal dalam pembentukan perilakunya terutama di bidang kesehatan, tidak hanya bekal pengetahuan dari kader kesehatan saja yang dibutuhkan dalam keberhasilan suatu penyuluhan, tetapi juga keterampilan dari kader kesehatan tersebut untuk menyampaikan informasi ${ }^{11}$. Melihat fenomena yang terjadi, peneliti berharap dengan adanya pendidikan kesehatan bisa merubah pengetahuan dan sikap seseorang. Oleh sebab itu semua orang itu berhak atas memperoleh pendidikan dan pengetahuan. Pendidikan kesehatan merupakan proses belajar yang harus dialami oleh individu, keluarga, kelompok, dan masyarakat yang menjadi sasaran dengan tujuan akhir perubahan perilaku. Maka peneliti tertarik untuk melakukan penelitian tentang pengaruh pemantauan 1000 Hari Pertama Kehidupan dalam pencegahan stunting melalui pelatihan kader kesehatan.

\section{Metode Penelitian}

Metode penelitian ini menggunakan jenis penelitian preexperimental design dalam bentuk pretes $t$ - posttest design. Peneliti membandingkan peningkatan pengetahuan dan sikap kader sebelum dan setelah diberikan pelatihan kesehatan menggunakan modul dan lembar balik tentang 1000 Hari Pertama Kehidupan. Penelitian ini dilaksanakan bulan September 2019. Populasi pada penelitian ini adalah seluruh kader kesehatan di Desa Menemeng Kecamatan pringgarata yang berjumlah 30 orang. Analisis data pada penelitian ini merupakan analisis univariat untuk mengetahui gambaran pengetahuan pre-test dan post-test berupa tabel frekuensi serta analisis bivariat dengan Uji Wilcoxon untuk melihat peningkatkan pengetahuan dan sikap kader tentang 1000 Hari Pertama Kehidupan. Kemaknaan hasil uji ditentukan berdasarkan nilai $\mathrm{p}<0,05$. Penelitian ini telah mendapatkan persetujuan dari Komite Etik Penelitian Kesehatan Universitas Mataram Fakultas Kedokteran.

\section{Hasil dan Pembahasan}

Tabel 1.1 Karakteristik Responden Berdasarkan Distribusi Frekuensi Kategori Umur, Pendidikan, Pekerjaan dan Lama Menjadi Kader Periode Agustus September $2018(n=30)$

\begin{tabular}{ccc}
\hline Karakteristik Kader & Jumlah & $\%$ \\
\hline Umur (tahun) & 5 & \\
$\leq 20$ & 15 & 16.6 \\
$21-35$ & 10 & 30 \\
$>35$ & 30 & 100.0 \\
\hline Jumlah & 33.4 \\
\hline
\end{tabular}




\begin{tabular}{lcc}
\hline Pendidikan & & \\
SD-SMP & 17 & 56.7 \\
SMA/SMK & 11 & 36.7 \\
Perguruan Tinggi & 2 & 6.6 \\
\hline Jumlah & 30 & 100.0 \\
\hline Pekerjaan & 15 & \\
$\quad$ IRT & 1 & 50 \\
Pegawai Swasta & 2 & 3.3 \\
$\quad$ Wiraswasta & 9 & 6.7 \\
$\quad$ Petani/Nelayan/Buruh & 3 & 30 \\
$\quad$ Lainnya & 30 & 10 \\
\hline Jumlah & 17 & 100.0 \\
\hline Lama Menjadi Kader (tahun) & 13 & 56.7 \\
$\quad \leq 3$ tahun & 30 & 43.3 \\
$\quad>3$ tahun & & 100.0 \\
\hline Jumlah & 23 & 76.7 \\
$\quad$ Jumlah Pelatihan & 7 & 23.3 \\
$\quad$ Tidak Pernah & 30 & 100.0 \\
$\quad$ Pernah & & \\
\hline Jumlah &
\end{tabular}

Berdasarkan tabel 1.1 dapat diketahui bahwa karakteristik responden berdasarkan Umur Kader Kesehatan di Desa Bagu, sebagian besar adalah responden termasuk dalam kategori umur 21-35 tahun yaitu sebanyak 15 responden $(50 \%)$. Hal ini menunjukkan bahwa semakin meningkatnya usia, semakin meningkat pula pengetahuan yang dimiliki. Semakin meningkatnya umur sejalan dengan semakin meningkatnya sikap terkait 1000 HPK. Hal ini diduga karena semakin bertambahnya umur, semakin berkembang pula daya tangkap dan pola pikir seseorang, sehingga pengetahuan yang diperoleh semakin membaik. Hal tersebut sejalan dengan pernyataan Rahmawati (2013), yang mengatakan bahwa semakin meningkat umur, maka persentase berpengetahuan semakin baik karena disebabkan oleh akses informasi, wawasan, dan mobilitas yang meningkat. Suharyat (2010) menyatakan bahwa pengetahuan tentang sesuatu adalah awal yang mempengaruhi sikap yang mungkin mengarah kepada suatu perubahan. Hal ini menunjukkan bahwa signifikannya hubungan antara usia dengan sikap terkait 1000 HPK erat kaitannya dengan pengetahuan yang dimiliki oleh responden ${ }^{12}$.

Menurut UU No. 20 tahun 2004 tentang Sistem Pendidikan Nasional bab VI, jenjang pendidikan formal dibagi menjadi pendidikan dasar mencakup Sekolah Dasar dan Sekolah Menengah Pertama atau sederajat, pendidikan menengah mencakup Sekolah Menengah Atas atau sederajat, dan Perguruan Tinggi. Jenjang pendidikan responden tersebar pada SD sampai dengan Perguruan Tinggi. Tidak ada responden yang tidak bersekolah. Berdasarkan hasil penelitian yang dilakukan, diketahui persentase pendidikan responden terbesar menempuh pendidikan hingga SD/SMP yaitu sebesar 17 responden $(56.7 \%)$. Sedangkan sebanyak 11 responden $(36,7 \%)$ menempuh pendidikan SMA/SMK, dan 2 
responden $(6,6 \%)$ menempuh perguruan tinggi. Tingkat pendidikan akan mempengaruhi penerimaan informasi dan nilai-nilai yang baru diperkenalkan. Hal ini juga sejalan dengan penelitian Rahmawati (2013) yang menyatakan bahwa semakin tinggi pendidikan, semakin mudah seseorang untuk menerima informasi sehingga memperbanyak pengetahuan yang dimiliki. Pendidikan juga akan membuat seseorang terdorong untuk ingin mencari tahu dan mencari pengalaman sehingga informasi yang diterima akan menjadi pengetahuan. Hubungan yang signifikan antara pendidikan dengan sikap terkait 1000 HPK diduga berkaitan erat dengan pengetahuan yang dimiliki oleh responden. Semakin meningkatnya pengetahuan, sikap yang dimiliki oleh responden juga akan menjadi lebih baik. Hal tersebut sesuai dengan penelitian Trisnawati et al. (2016) dimana sebagian responden yang memiliki pengetahuan yang baik juga memiliki sikap yang mendukung terhadap pentingnya gizi 1000 HPK.

Pekerjaan dikategorikan menjadi enam jenis pekerjaan, yaitu tidak bekerja, PNS, pegawai swasta, wirausaha, petani atau nelayan atau buruh, dan lainnya. Sebanyak 15 (50\%) responden menjadi IRT, 1 responden $(3,3 \%)$ pegawai swasta, 2 responden $(6,7 \%)$, petani/nelayan/buruh 9 responden (30\%) wirausaha, dan 3 responden (10\%) lainnya. Pekerjaan dapat memengaruhi pengetahuan seseorang lewat informasi yang berada di lingkungan pekerjaan tersebut. Kelompok kerja yang efektif terlibat dalam berbagi pengetahuan eksternal mencakup pertukaran informasi dan umpan balik dengan pelanggan, pakar organisasi, dan pihak lain diluar kelompok. Sehingga, diduga pekerjaan tersebut memungkinkan berhubungan dengan profesi tertentu maupun langsung mendapatkan akses informasi yang dapat memengaruhi pengetahuan responden mengenai 1000 $\mathrm{HPK}^{1}$.

Tabel 1.2 diatas menunjukkan bahwa responden yang bekerja kurang dari 3 tahun sebesar 17 responden $(56,7 \%)$ dan yang bekerja lebih dari 3 tahun yaitu sebesar 13,3 (43,3\%). Hal ini sesuai dengan Manddalak (2012) mengatakan bahwa lamanya menjadi kader kinerja masa lalu cenderung dihubungkan pada hasil seseorang, semakin lama ia bekerja maka semakin terampil dalam melaksanakan tugasnya sehingga senioritas dalam bekerja akan lebih terfokus jika dibandingkan dengan orang yang baru bekerja.

Dari segi jumlah pelatihan yang diikuti kader menunjukkan bahwa sebagian besar responden tidak pernah mengikuti pelatihan yaitu sebesar 23 responden $(76,7 \%)$, dibandingkan dengan responden yang pernah mengikuti pelatihan yaitu sebesar 7 responden (23,3\%).

\section{Perbedaan Skor Pretest dan Post Test Pengetahuan Responden}

Pengetahuan tentang 1000 HPK responden didapatkan dari kuesioner yang diberikan kepada responden. Sebanyak 20 pertanyaan tentang 1000 HPK diberikan dalam bentuk pertanyaan tertutup dengan 3 pilihan jawaban dengan satu jawaban yang tepat. 


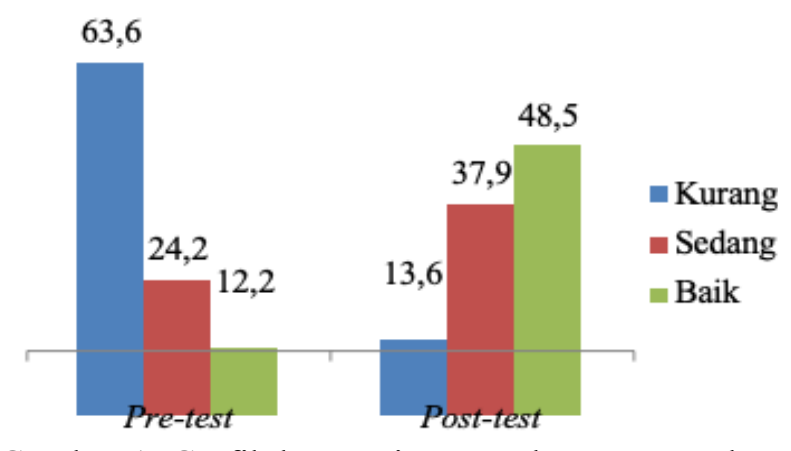

Gambar 1. Grafik katagori pengetahuan responden

Berdasarkan tabel diatas, dapat dilihat bahwa sebelum dilakukan pelatihan terkait 1000 HPK, sebagian besar (63.6\%) responden memiliki pengetahuan kurang, yaitu sebanyak 19 responden. Kemudian hanya sebanyak 7 orang $(24.2 \%)$ responden memiliki pengetahuan sedang, dan sebanyak 4 responden $(12.2 \%)$ responden memiliki pengetahuan baik. Pendidikan yang tinggi berhubungan dengan kemudahan untuk mendapat informasi, sedangkan pekerjaan berhubungan dengan pertukaran informasi yang terdapat di lingkungan kerjanya. Setelah diberikan pelatihan, dapat terlihat bahwa kategori kurang menurun drastis sedangkan kategori sedang dan baik bertambah. Sebanyak 4 responden (13.6\%) masih memiliki pengetahuan kurang, tetapi sebanyak 11 responden $(37.9 \%)$ memiliki pengetahuan sedang dan sebanyak 15 responden $(48.5 \%)$ memiliki pengetahuan baik. Peningkatan pengetahuan juga dapat dilihat berdasarkan sebaran topik terkait 1000 HPK.

\section{Perbedaan Skor Pretest dan Posttest Sikap Responden}

Sikap yang dilakukan responden dalam penelitian ini bukanlah sesuatu yang sudah dilakukan, tetapi merupakan gambaran atau refleksi yang akan dilakukan responden tersebut sikap tentang 1000 HPK responden didapatkan dari kuesioner yang diberikan. Kuesioner berbentuk pernyataan normal dengan pilihan setuju dan tidak setuju. Kategori sikap dibagi menjadi 3 kelompok, yaitu kurang $(<60 \%)$, sedang $(60 \%-79 \%)$, dan baik ( $\geq 80 \%)$. Berikut grafik kategori sikap responden.

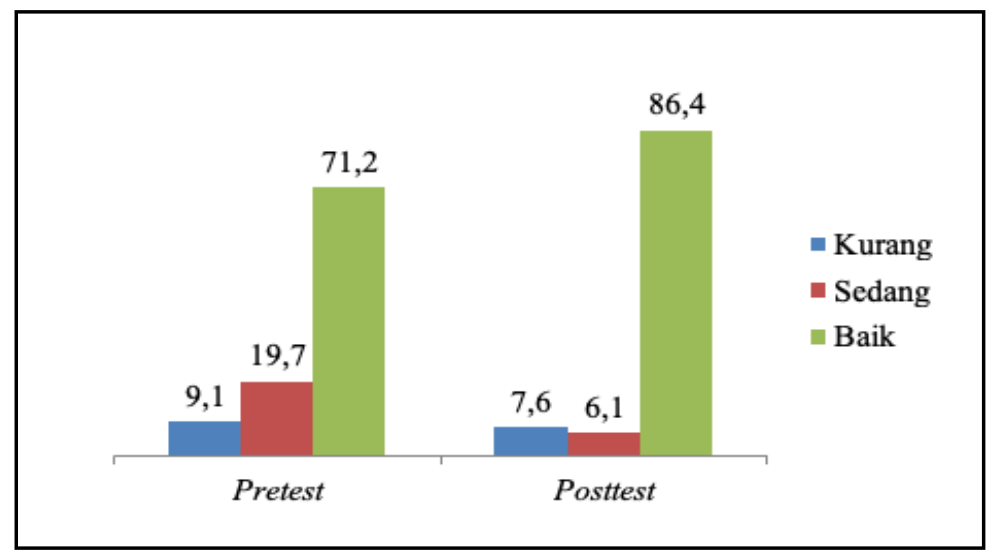


Berdasarkan tabel diatas, dapat dilihat bahwa sebelum dilakukan pelatihan terkait 1000 HPK, sebagian besar (71.2\%) responden sudah memiliki sikap baik, yaitu sebanyak 47 responden. Kemudian hanya sebanyak 13 orang $(19.7 \%)$ responden memiliki sikap sedang, dan sebanyak 6 responden $(9.1 \%)$ responden memiliki sikap kurang. Setelah diberikan pelatihan, dapat terlihat bahwa kategori baik meningkat sedangkan kategori sedang dan kurang menurun. Sebanyak 5 responden (7.6\%) masih memiliki sikap kurang dan sebanyak 4 responden $(6.1 \%)$ memiliki sikap sedang, tetapi sebanyak 57 responden (86.4\%) memiliki sikap baik. Sebagian besar responden memiliki sikap yang baik pada pre-test walaupun memiliki pengetahuan kurang. Menurut Notoatmodjo (2010), penentuan sikap tidak hanya dipengaruhi oleh pengetahuan, tetapi juga keyakinan yang dimiliki oleh seseorang, termasuk dalam menyikapi pendidikan yang diberikan. Sehingga, diduga responden memiliki kepercayaan yang mengarahkan kepada sikap yang baik walaupun tdiak memiliki pengetahuan tentang hal itu. Diduga pula karena terdapat kecenderungan individu untuk memilih pernyataan yang sesuai norma karena penyataan sikap yang cenderung menggiring. Peningkatan sikap juga dapat dilihat berdasarkan sebaran topik terkait 1000 HPK.

\section{Pembahasan}

Pemberian pelatihan selama tiga hari diharapkan dapat meningkatkan pengetahuan dan sikap responden terkait 1000 HPK. Pengetahuan dan sikap responden yang dinilai melalui jawaban kuesioner kemudian diuji menggunakan SPSS 19.0. Uji yang dilakukan yaitu uji Wilcoxon dimana data yang digunakan merupakan data berpasangan dari satu responden. Berdasarkan hasil uji komparatif Wilcoxon, dapat diketahui bahwa nilai rata-rata post-test lebih tinggi daripada pre-test dengan nilai minimum dan maksimum yang juga lebih tinggi. Nilai rata-rata naik dari 50.37 menjadi 75.07, sedangkan nilai minimum pre-test sebesar 10 naik menjadi 30 di post-test, dan nilai maksimum di pre-test sebesar 90 menjadi 100 di post-test. Hasil dari perhitungan Wilcoxon Signed Rank Test menunjukkan nilai $p$ value (asymp. Sig. 2 tailed) sebesar 0.000. Hal ini menunjukkan terdapat perbedaan yang bermakna antara pre-test dan post-test pengetahuan terkait 1000 HPK.

Menurut hasil uji, terdapat 1 responden yang nilai post-test nya lebih rendah dibandingkan pre-test dan 1 responden yang memiliki nilai post-test sama dengan pre-test. Sebanyak 64 responden lainnya memiliki nilai post-test yang meningkat dari nilai pre-test. Hal ini menunjukkan bahwa tidak semua responden mengalami peningkatan pengetahuan setelah diberikan edukasi. Octamelia (2012) menyatakan bahwa keberhasilan dari penyuluhan dipengaruhi oleh beberapa faktor, yaitu tingkat pendidikan, tingkat sosial ekonomi, adat istiadat, kepercayaan masyarakat, dan ketersediaan waktu di masyarakat. Masyarakat menganggap adat istiadat adalah sesuatu yang tidak boleh diabaikan, masyarakat juga lebih memperhatikan informasi yang disampaikan oleh orang-orang yang sudah mereka kenal karena sudah timbul kepercayaan masyarakat dengan penyampai informasi. 
Selain pengetahuan, pre-test dan post-test dari sikap terkait 1000 HPK juga diuji komparatif menggunakan uji Wilcoxon. Secara deskriptif, perbedaaan nilai rata-rata pre-test dan post-test responden hanya sebesar 0.05 dengan nilai minimum yang meningkat sedangkan nilai maksimum tetap. Nilai minimun pretest sebesar 4 meningkat menjadi 6 pada post-test, sedangkan nilai maksimum tetap berada pada nilai 12 . Besarnya perbedaan ini dilihat dengan uji Wilcoxon bermakna secara statistik. Hasil dari perhitungan Wilcoxon Signed Rank Test menunjukkan nilai $p$ value (asymp. Sig. 2 tailed) sebesar 0.004. Hal ini menunjukkan terdapat perbedaan yang bermakna antara pre-test dan post-test sikap karena nilai $\mathrm{p}<0.05$. Berdasarkan hasil uji Wilcoxon, dapat diketahui bahwa sebanyak 11 responden mengalami penurunan nilai pada hasil post-test mereka dan sebanyak 26 responden memiliki nilai post-test yang sama dengan pre-test. Hanya sebanyak 29 responden yang mengalami peningkatan nilai post-test. Hal ini disebabkan karena banyaknya responden yang sudah memiliki sikap sesuai norma dan termasuk kategori baik pada hasil pre-test.

Media dan teknologi berpengaruh banyak dalam pendidikan, terutama karena menawarkan banyak kemungkinan untuk terjadinya peningkatan kegiatan belajar mengajar. Keberadaan media adalah memfasilitasi komunikasi antara sumber informasi dan penerima informasi ${ }^{3}$. Terdapat empat faktor yang mempengaruhi pembelajaran dengan media, yaitu materi ajar, karakteristik pembelajar, aktivitas belajar, dan evaluasi. Karakteristik materi ajar berupa 1000 HPK mencakup masa sebelum kehamilan, awal kehamilan, sampai bayi lahir dan bayi diberikan makanan pendamping ASI hingga usia 2 tahun. Materi ini memiliki tingkat kesulitan yang beragam karena terdapat beberapa informasi yang sebelumnya tidak diketahui sama sekali oleh masyarakat luas. Sehingga untuk beberapa soal yang tidak diketahui responden menebak atau memilih pilihan yang dianggap paling benar bukan berdasarkan pengetahuan ${ }^{3}$.

Faktor kedua yang mempengaruhi pembelajaran dengan media adalah karakteristik pembelajar. Pembelajar, yang dalam penelitian ini calon pengantin wanita, memiliki karateristik yang berbeda-beda. Berdasarkan hasil uji Spearman, usia, pendidikan, dan pendapatan responden mempengaruhi pengetahuan yang dimiliki oleh responden. Namun, rasa ingin tahu yang dimiliki responden juga berpengaruh. Semakin tinggi rasa ingin tahu yang dimiliki, responden akan memperhatikan penyuluhan maupun konseling dengan seksama dan lebih mudah menerima materi yang diberikan. Selanjutnya faktor ketiga berupa aktivitas belajar. Pada penyuluhan, materi diberikan dengan metode ceramah dan responden diberikan media berupa modul dan lembar balik yang diberikan satu untuk setiap responden. Sedangkan pada metode konseling, responden diberikan materi sambil menunjukkan bagian materi pada modul. Media modul dan lembar balik diberikan agar selain mendengar, responden juga memperhatikan dan melihat gambar yang terdapat pada media sehingga lebih mudah untuk memahami materi. Aktivitas belajar yang dilakukan juga dipengaruhi oleh gaya belajar dari responden tersebut. Beberapa responden fokus mendengarkan saat pemberian 
materi, beberapa lainnya fokus membaca media saja. Kemudian faktor terakhir yang mempengaruhi pembelajaran yaitu evaluasi yang dilakukan. Dalam penelitian ini evaluasi yang diberikan berupa pertanyaan post-test dari materi yang sudah diberikan. Post-test ini mencakup pengetahuan dan juga sikap terkait 1000 HPK.

Hasil penelitian ini membuktikan bahwa intervensi berupa pelatihan yang dilakukan mampu meningkatkan pengetahuan dan sikap terkait 1000 HPK. Hal ini sesuai dengan hasil uji Wilcoxon maupun peningkatan nilai responden pada post-test pengetahuan dan sikap. Handayani dan Istrini (2010) menyatakan bahwa media dapat membantu pemahaman seorang pembelajar. Ketika dalam media disertakan gambar, materi akan lebih mudah dipahami dengan lengkap dan tepat. Penyuluhan kesehatan berkaitan dengan perubahan-perubahan yang dapat mengubah perilaku dan membantu pencapaian tujuan yang diinginkan, sehingga setelah penyuluhan terjadi perbedaan yang bermakna pada pengetahuan dan sikap responden.

Teori Benyamin Blum menyatakan bahwa pengetahuan merupakan domain yang sangat penting untuk terbentuknya tindakan seseorang. Teori tersebut juga menjelaskan bahwa perilaku merupakan faktor terbesar kedua setelah faktor lingkungan yang mempengaruhi kesehatan individu maupun masyarakat. Oleh sebab itu, dalam rangka mewujudkan generasi masa depan yang lebih baik, intervensi terkait 1000 HPK terhadap faktor perilaku sangat penting. Perilaku yang didasari oleh pengetahuan akan lebih baik daripada perilaku yang tidak didasari pengetahuan. Intervensi terhadap faktor perilaku ini dapat berupa pemberian pelatithan yang mampu merubah sikap dan perilaku. Pengetahuan terkait 1000 HPK sangat penting untuk terjadinya perubahan perilaku. Dengan meningkatnya pengetahuan dan sikap terkait 1000 HPK, diharapkan dapat mendorong praktik gizi yang lebih baik pada kader kesehatan, sehingga kader kesehatan dapat memberikan informasi kepada ibu hamil sejak dini dan menghasilkan keturunan yang lebih baik serta kualitas hidup yang lebih baik ${ }^{13}$.

Dalam penelitian yang dilakukan oleh Maddalak (2012) tentang Pengaruh pelatihan kader terhadap tingkat pengetahuan dan sikap kader tentang tugas kader Posyandu, hasil evaluasi menunjukkan terjadinya peningkatan pengetahuan peserta yang mendapatkan nilai dengan kriteria baik sebesar $100 \%$ yang sebelumnya rata-rata kader berpengetahuan kurang. Peningkatan pengetahuan disebabkan oleh karena peserta memperhatikan dengan seksama hal-hal yang disajikan pemateri sehingga apa yang disampaikan oleh pemateri dapat mereka serap dengan baik. Hal tersebut juga dapat disebabkan oleh kejelasan materi, penggunaan bahasa yang komunikatif, alat peraga pengajaran, metode mengajar yang tepat, serta kesiapan peserta pelatihan.

Kemampuan kader akan menjadi lebih baik setelah mengikuti pelatihan sehingga pemahaman tentang pemantauan 1000 HPK akan menjadi lebih tahu dan faham. Hal ini tentunya disebabkan pengetahuan yang meningkat yang didapat kader selama dalam pelatihan yang dilakukan dengan perhatian, keaktifan selama 
proses pelatihan. Salah satu indikator pencapaian keberhasilan proses pelatihan kader dapat dilihat dari daya serap bahan materi yang diajarkan. Untuk itu seorang narasumber harus benar-benar menguasai dan memahami materi pelatihan sebelum mengajar dan mengetahui bagaimana cara menyampaikannya kepada kader hingga mereka dapat memahaminya. Jika narasumbernya menarik pasti juga kader selaku peserta juga akan senang mengikutinya. Di dalam penelitian ini, saat pelatihan berlangsung, terlihat responden aktif dalam setiap diskusi maupun dengan mau bertanya dan bertukar pikiran pengalaman mereka selama mereka melaksanakan tugas sebagai kader. Hal tersebut menunjukan bahwa dengan pelatihan yang diberikan maka akan merubah tingkat pengetahuan seseorang menjadi lebih baik.

\section{Kesimpulan}

Pelatihan dengan modul dan lembar balik dapat meningkatkan pengetahuan dan sikap tentang 1000 Hari Pertama Kehidupan pada kader kesehatan. Bagi peneliti selanjutnya, disarankan agar meneliti tentang metode promosi kesehatan yang lain, tidak hanya tentang pengetahuan 1000 Hari Pertama Kehidupan, sehingga berbagai metode promosi kesehatan semakin berkembang.

\section{Daftar Pustaka}

1. Cummings JN. 2004. Work Groups, Structural Diversity, and Knowledge Sharing in a Global Organization. Management Science 50(3):352-364

2. Dinas Kesehatan Kabupaten Lombok Tengah.2018.

3. Handayani L, Ristrini. 2010. Pengaruh Model Pembelajaran Kesehatan Menggunakan Multimedia terhadap Perubahan Pengetahuan dan Sikap Siswa SLTP terkait Faktor Risiko Penyakit jantung Koroner. Buletin Penelitian Sistem Kesehatan 13(4): 334-343

4. Kementerian Kesehatan Republik Indonesia. 2011. Buku Panduan Kader Posyandu Dalam Menuju Keluarga Sadar Gizi. Jakarta: Kemenkes RI. Diakses pada tanggal 15 November 2019 di http://promkes.depkes.go.id

5. Kemenkes RI. 2018. Riset Kesehatan Dasar ; RISKESDAS. Jakarta: Balitbang Kemenkes RI

6. Kementrian Sosial Republik Indonesia. 2015. 1000 Hari Pertama Kehidupan Penentu Ribuan Hari Berikutnya. Tangerang Selatan: Wahana Visi Indonesia. $\quad$ Diakses 18 Maret 2019, http://wvindonesia.org/images/article/4141/Aksi\%20Gizi\%20Booklet.pdf

7. Kusumawardani E. 2012. Pengaruh Penyuluhan Kesehatan terhadap Tingkat Pengetahuan, Sikap, dan Praktik Ibu dalam Pencegahan Demam Berdarah Dengue pada Anak [karya tulis ilmiah]. Semarang (ID): Universitas Diponegoro

8. Maddalak.2012.Pengaruh pelatihan kader terhadap tingkat pengetahuan dan sikap kader tentang tugas kader Posyandu. Diakses pada tanggal 15 November 2019

9. Notoatmodjo S. 2007. Promosi Kesehatan dan Ilmu Perilaku. Jakarta (ID): Rineksa Cipta

10. Pusat Data dan Informasi Kementerian Kesehatan. 2018. Situasi Balita Pendek di Indonesia. Jakarta 
11. Rahmawati A, Bahar B, Salam A. 2013. Hubungan antara Karakteristik Ibu, Peran Petugas Kesehatan dan Dukungan Keluarga dengan Pemberian Asi Eksklusif di Wilayah Kerja Puskesmas Bonto Cani Kabupaten Bone [skripsi]. Makassar (ID): Universitas Hasanuddin.

12. Suliha et al. 2002. Pendidikan Kesehatan dalam Keperawatan. Jakarta : Penerbit Buku Kedokteran EGC.

13. Suharyat Y. 2010. Hubungan antara Sikap, Minat, dan Perilaku Manusia. Region 1(2): 1-19

14. Trisnawati Y, Purwanit S, Retnowati M. 2016. Studi Deskriptif Pengetahuan dan Sikap Ibu Hamil tentang Gizi 1000 Hari Pertama Kehidupan di Puskesmas Kokaraja Kabupaten Banyumas. Jurnal Kebidanan 08(02): 127224 